\title{
Adherence of a Clinical Strain of Mycoplasma fermentans to Human Cultured Epithelial Cells
}

\author{
Mónica Rosales-Pérez ${ }^{1,2 *}$, Silvia Giono-Cerezo², Jorge Girón ${ }^{3}$, Antonio Yáñez ${ }^{4}$, \\ Lilia Cedillo ${ }^{3,5}$ \\ ${ }^{1}$ Facultad de Agrobiología, Universidad Autónoma de Tlaxcala, México \\ ${ }^{2}$ Escuela Nacional de Ciencias Biológicas, I.P.N, México, D. F. México \\ ${ }^{3}$ Centro de Detección Biomolecular, VI.E.P., B.U.A.P. Puebla, Pue, México \\ ${ }^{4}$ Facultad de Estomatología, B.U.A.P. Puebla, México \\ ${ }^{5}$ Centro de Investigaciones en Ciencias Microbiológicas, Instituto de Ciencias, B.U.A.P., Puebla, Pue, México

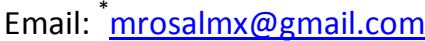

Received 27 June 2014; revised 26 July 2014; accepted 27 August 2014

Copyright (C) 2014 by authors and Scientific Research Publishing Inc.

This work is licensed under the Creative Commons Attribution International License (CC BY).

http://creativecommons.org/licenses/by/4.0/

\section{cc) (7) Open Access}

\section{Abstract}

This study compares the kinetics of adherence of both the prototype strain PG-18 and the recently clinically isolated strain P-140 of Mycoplasma fermentans to HEp-2 cells. M. fermentans may induce respiratory and genitourinary tract infections. We investigated the presence of putative adhesins from strain P-140. A surface protein of $47 \mathrm{kDa}$, labeled SP47, isolated from M. fermentans P-140, seems to be involved in acterial adherence on HEp-2 cells; this study could allow helping understand the interaction between mycoplasmas and their hosts. Anti-SP47 antibodies inhibited the formation of bacterial clusters and adherence to cultured cells, quantified by ELISA. M. fermentans P-140 was more efficient at adhering to cultured HEp-2 cells than PG-18.

\section{Keywords}

Mycoplasma fermentans, Mycoplasmas, Adherence, Pathogenesis

\section{Introduction}

Mycoplasmas are the smallest self-replicating organisms; some species are pathogenic for humans. They lack a rigid cell wall and are bounded by a single membrane — the plasma membrane. Most mycoplasmas are parasites,

\footnotetext{
*Corresponding author.
}

How to cite this paper: Rosales-Pérez, M., Giono-Cerezo, S., Girón, J., Yáñez, A. and Cedillo, L. (2014) Adherence of a Clinical Strain of Mycoplasma fermentans to Human Cultured Epithelial Cells. Advances in Microbiology, 4, 726-735. 
exhibiting strict host and tissue specificities [1]. The intimate interaction with eukaryotic cells and in some cases the subsequent invasion into or fusion with these cells causes cell damage. Mycoplasmas also modulate the activity of host cells via various direct mechanisms and/or indirectly by cytokine-mediated effects [2] [3]. Mycoplasmas colonize the epithelial respiratory and urogenital tracts like typical surface parasites [4] [5]. A key requirement for successful colonization by mycoplasmas is their adherence to the epithelial cells surface, considered as the major virulence factor of mycoplasmas [6]-[8]. Adhesins must be part of their cell membranes [9] and many adhering mycoplasmas display specialized polar-like tip structures [8] that mediateattachment to host cells. Most studies about mycoplasma adhesion have focusedon human pathogens like M. pneumoniae [8], M. genitalium [4], M. hominis [10], M. penetrans [11] and Ureaplasma urealyticum [12].

To understand mycoplasma-host interactions it is important to define surface constituents as indicators of potential diversity in these organisms and as functional products that contribute to their adaptive capabilities [13] [14]. M. fermentans shows a different profile of surface proteins and lipoproteins which involves the expression of a strain-variant surface proteins family [13] [15]. Phase variation of surface epitopesin M. fermentans appears to involve differential accessibility of expression of surface lipoproteins [16]. Differential masking may be an important mechanism for altering the antigenic or functional surface topology of this mycoplasma and other mycoplasmas. Analysis of the mechanisms of variation and the antigenictopology of lipoproteins is a critical issue for several mycoplasma species, including $M$. fermentans [16]. M. fermentans is currently being examined as an agent potentially associated with human diseases, including infectious processes affecting immunocompromised individuals and patients with rheumatoid arthritis [17]-[19]. In a previous study, we induced experimental arthritis injecting the bacteria (M. fermentans P-140) in the knee joints of rabbits, which resulted in a systemic infection demonstrating the microorganism's ability to disseminate throughout the animal [20]. In a recent paper we have shown that $M$. fermentans is able to produce severe respiratory disease in a hamster model [21].

The aims of this study were to investigate the adherence properties of $M$. fermentans P-140, to do an ultrastructural analysis and to identify putative adhesions involved in adherence of this emergent microorganism.

\section{Methods}

\subsection{Organisms and Culture Conditions}

Mycoplasmas used in the adherence assays were: M. fermentans P-140 strain (isolated at the Laboratory of Mycoplasmas of the Institute of Sciences, Universidad Autónoma de Puebla, Puebla, México, from the respiratory tract of a patient with asthma; M. fermentans PG-18 and M. pneumoniae Eaton strains (kindly donated by Dr. Gail H. Cassell, University of Alabama, Birmingham); also M. fermentans incognitus strain (kindly donated by Dr S.C. Lo, Armed Forces Institute of Pathology, Washington DC) were used to compare the protein profiles.

Mycoplasmas were routinely grown in SP-4 broth and E broth supplemented with glucose and horse serum at $37^{\circ} \mathrm{C}$ until they reached late exponential phase of growth (pH 6.5). The bacteria was pelleted by centrifugation at 10,000 rpm for $15 \mathrm{~min}$, washed, and re-suspended in a solution containing $10 \mathrm{mM}$ PBS, $0.15 \mathrm{M} \mathrm{NaCl}$ (pH 7.2). The cellular line Hep-2 was maintained and propagated in Dulbecco's minimal essential medium (DMEM, Gibco BRL) containing $10 \%$ fetal bovine serum (Gibco, BRL), under $5 \% \mathrm{CO}_{2}$ at $37^{\circ} \mathrm{C}$ [11].

\subsection{Adherence Assays Kinetics and Inhibition of Adherence}

The adherence kinetics of $M$. fermentans (P-140 and PG-18 strains) to HEp-2 cellswas evaluated by Giemsa staining and light microscopy and by ELISA, using specific antibodies against $M$. fermentans. Cell culture was grown to confluence inninety-six well microtiter plates (Nunc). Wells were washed twice with DMEM (Gibco, $\mathrm{BRL}$ ) and cells were then infected with an inoculum concentration of $10^{6} \mathrm{UFC} / \mathrm{ml}$ of each mycoplasma and incubated at $37^{\circ} \mathrm{C}$ in a partial $\mathrm{CO}_{2}$ atmosphere inthe same medium. Each infected culture was evaluated at 0,30 min, 2, 4, 6, 8, 12, 24, and 72 hours under the following conditions: without serum, with or without $1 \%$ mannose [11].

Giemsa stain was used to visualize the adherent microorganisms. Cyt adherent mycoplasmas were detected with mycoplasma-specific polyclonal antibodies incubated for 2 hours at $37^{\circ} \mathrm{C}$ and the anti-rabbit IgG-phosphatase alkaline conjugate antiserum at $405 \mathrm{~nm}$ by ELISA [22]. The adherence inhibition assays were done in triplicate in 96 well plates, $10 \mu \mathrm{l}$ of a mycoplasma suspension $\left(10^{6} \mathrm{UFC} / \mathrm{ml}\right)$ were added to individual wells and were incubated with different dilutions (1:10, 1:25, 1:50, 1:100) from the processed antiserum (anti-SP47 of $M$. 
fermentans P140), and normal rabbit serum. The degree of adherence inhibition was compared with the wells that contained only mycoplasmas and epithelial cells. The inhibition of the adhesion was also quantified by ELISA, (Multiskanex, Lab Systems) [22].

\subsection{Immunofluorescence Microscopy}

M. fermentans adherence to epithelial cells was studied as previously described. After infected cells were washed with PBS and fixed with 3\% formaldehyde for $40 \mathrm{~min}, 30 \mu \mathrm{l}$ of the antibody anti-M. fermentans (1:50) were added, incubated at $37^{\circ} \mathrm{C}$ for $40 \mathrm{~min}$ in a humid atmosphere, then $30 \mu \mathrm{l}$ of anti-rabbit fluorescein-labeled IgG (anti-IgG-FITC) were added, incubated at $37^{\circ} \mathrm{C}$ under the same conditions [23]. Specimens were observed in a Nikon Diaphot 300 epifluorescence microscope.

\subsection{Electron Microscopy.}

Ultrastructural examination of $M$. fermentans cultures and the interaction of microorganisms with the epithelial cells were examined using a JEOL XII transmission electron microscope. Samples were fixed with $3 \%$ glutaraldehyde in cacodylate buffer $(0.1 \mathrm{M}$; $\mathrm{pH} 7.3)$ overnight at $4^{\circ} \mathrm{C}$, ultrathin sections were processed for transmission electron microscopy (TEM) and $M$. fermentans P-140 was stained whit $1 \%$ phosphotungstic acid.

\subsection{Extraction of Mycoplasma Surface Proteins.}

The microorganisms in late exponential phase of growth were harvested in $50 \mathrm{mM}$ sodium bicarbonate buffer (pH 8.0) or $10 \mathrm{mM}$ PBS, $0.15 \mathrm{M} \mathrm{NaCl}$ (pH 7.2) toeliminate residual media. Mycoplasmas were then suspended in lysis buffer ( $35 \mathrm{mMTris} \mathrm{pH}$ 8.2, $0.25 \mathrm{M} \mathrm{NaCl}, 16 \mathrm{mg} / \mathrm{ml}$ of sodium deoxicholate, $0.1 \%$ sodium dodecylsulfate (SDS) and $1 \mathrm{mM}$ phenylmethyl sulfonyl fluoride) and incubated $30 \mathrm{~min}$ at $37^{\circ} \mathrm{C}$ [2] [9]. The suspension was centrifuged at 10,000 rpm for 1 hour at $4^{\circ} \mathrm{C}$ toobtain a cell-free supernatant fraction of mycoplasma surface proteins. The surface proteins were separated by SDS-PAGE [24].

\subsection{Antisera and Cell Culture}

Rabbit polyclonal antiserum against M. fermentans P-140 and PG-18 were raisedin rabbits (female, 2 kg weight) immunized with four doses of whole bacterium fixed with $3 \%$ formaldehyde emulsified in complete Freund's adjuvant (first dose) or in complete Freund's adjuvant (3 extra doses were administered on days 21, 28 and 35). Doses contained $100 \mathrm{mg}$ protein and were administered subcutaneously in $1 \mathrm{ml}$. The rabbits were bled 7 days after the last dose and the serum obtained was kept at $-20^{\circ} \mathrm{C}$. The anti-mycoplasma membrane proteins (anti-SP and anti-SP47) antisera were obtained according to the immunization scheme describe dearlier. The titer of antibodies in the sera was determined by ELISA [22]. Rabbitpre-immunization serum was used as a negative control in the studies described below. Anti-rabbit IgG labeled with alkaline phosphatase and anti-rabbit IgG-FITC (fluorescein isothiocyanate) from Sigma Chemical Co. were used in the studies described below.

\subsection{Immunoblotting of Surface Proteins of $M$. fermentans}

Surface proteins of $M$. fermentans were analyzed by SDS-PAGE. They were transferred to membranes of PVDF (Immobilon-PVDF, Millipore, Co.) using a semidrytrans-blot SD Apparatus Bio-Rad Laboratories to $20 \mathrm{v}$ during $20 \mathrm{~min}$.

Membranes were blocked with 5\% milk in PBS-T (phosphate buffered saline-tween 20) for 2 hours, washed with PBS-T, and then incubated with antibody anti-SP47 oranti-M. fermentans antiserum diluted 1:2500 for 1 hour in constant agitation. The membranes were washed and incubated with anti-rabbit IgG labeled with alkaline phosphatase antiserum (diluted 1:30,000) (Sigma, Chemical Co.). The reaction was developed using a mixture of NBT/BCIP (nitro blue tetrazolium/5-bromo-4 chloro-3-indolyl phosphate) in alkaline phosphatase buffer (pH 9.5) [23].

\section{Results}

\subsection{M. fermentans Adherence to Cultured Epithelial Cells}

The adhesion kinetics of two strains of M. fermentans (P-140 and PG-18 strains) to cultured epithelial cells was 
analyzed between 0 and 72 hours of infection, Figure 1. Early in the infection, Giemsa-stained M. fermentans organisms adhered to the host cell surface as single organisms but then they formed tight micro colonies that increased in size as the infection progressed; see Figures 1(A)-(C). We observed that between 6and 8 hours of infection the organisms had formed defined clusters on restrictedareas of the cell; see Figure 1(D), Figure 1(E). Beyond 12 hours of infection the mycoplasmas formed aggregates covering large extensions of the surface of cultured cells as is shown in Figures $1(\mathrm{~F})-(\mathrm{H})$.

This analysis showed a time-dependent binding profile, confirming the specific interaction between these mycoplasmas with epithelial cells, see Figure 2. The data obtained in these experiments showed that P-140 adheres more than PG-18 to HEp-2 cells, which agrees with the light microscopy observations shown in Figure 1.

The time-dependent association of $M$. fermentans with HEp-2 cells was also demonstrated by indirect immunofluo rescence using anti- $M$. fermentans antibodies. An increase of specific fluorescence was seen as the time of infection increased which was manifested by the presence of fluorescent bacterial clusters on the host cells, Figure 3. The normal rabbit antiserum revealed no fluorescent clusters demonstrating the specificity of the reaction. These observations confirmed the data shown above. Epithelial cell damage in arthritis promotes the growth of mycoplasmas through the release of substances which can be used as nutrients by mycoplasmas.

Mycoplasmal products could stimulate the secretion of cytokines involved in the development of arthritis [20] and could create the basis for further damage to the joint.

\subsection{Ultrastructural Analysis}

Cell adherence of M. pneumoniae has been demonstrated to be mediated by multiple interacting proteins localized in the terminal tip organelle of the organism [25] [26]. However, this tip organelle structure has not been
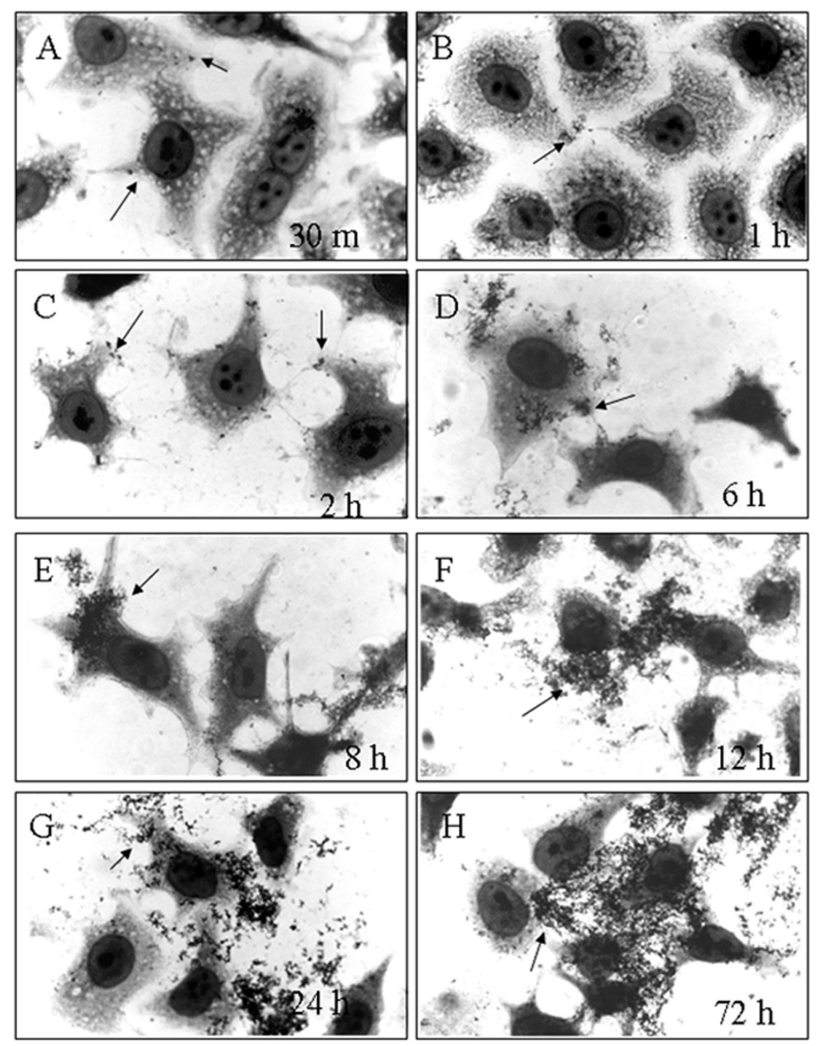

Figure 1. Kinetics of adherence of $M$. fermentans Hep-2 cells. Giemsa stain of epithelial HEp-2 cells infected with $M$. fermentans P-140 strain during $30 \mathrm{~min}(\mathrm{~A}), 1 \mathrm{~h}$ (B), $2 \mathrm{~h} \mathrm{(C),} 6 \mathrm{~h}$ (D), $8 \mathrm{~h}$ (E), $12 \mathrm{~h}(\mathrm{~F}), 24 \mathrm{~h}(\mathrm{G})$, and $72 \mathrm{~h}(\mathrm{H})$ at $37^{\circ} \mathrm{C}$. The arrows indicate the location of the cumulus of bacteria adhered to cells. Magnification $100 \times$. 


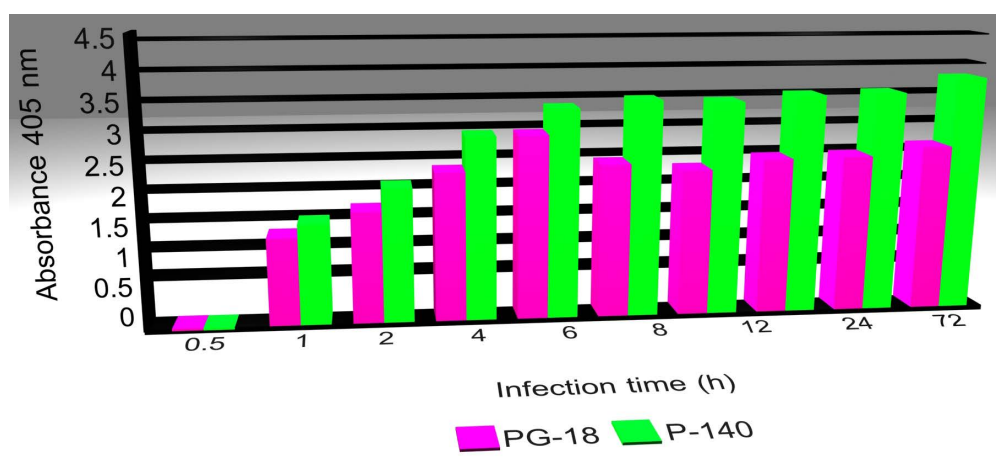

Figure 2. Adherence kinetics of $M$. fermentans to epithelial cells. The increase in the number of bacteria adhered to cells in agreement with the time of infection can be appreciated. $M$. fermentans P140 ( $\cdots)$, M. fermentans PG-18 ( $\cdots)$. Each value represents the mean of three independient experiments performed in triplicate.
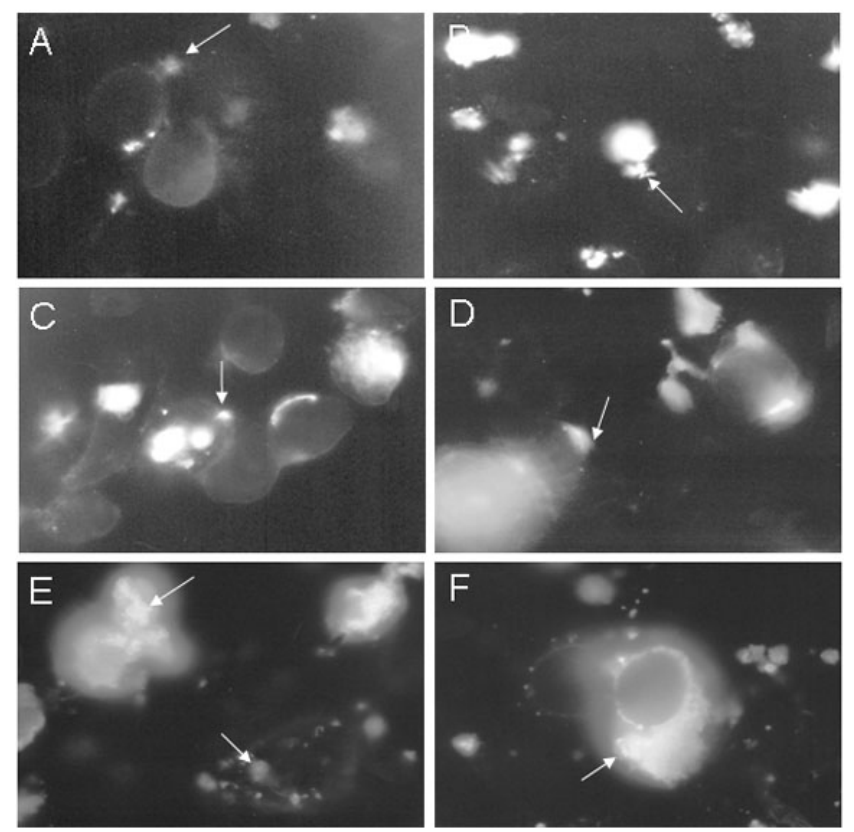

Figure 3. Kinetics of adherence by immunofluorescence. Immunofluorescence of infected HEp-2 cells with $M$. fermentans P-140 during 30 min (A), 1 h (B), 2 h (C), 6 h (D), 12 h (E), 72 h (F) at $37^{\circ} \mathrm{C}$. Mycoplasmas were confirmed using antiserum against $\mathrm{M}$. fermentans P-140 and antiserum anti-rabbit $1 \mathrm{~g} \mathrm{G}$ labelled with FITC. Magnification 100×.

observed on the majority of mycoplasma species, although individual surface protein adhesins have been defined and partially characterized [10] [27]. We were interested in determining if both $M$. fermentans strains studied here possessed a tip organelle. To address this aim, we performed ultrastructural studies by electron microscopy of both P-140 and PG-18 grown in SP-4 broth and E broth until they reached late exponential phase. Bacteria was applied to a copper 300-mesh electron microscopy grid covered with a Formvar film and negatively stained with $1 \%$ phosphotungstic acid $\mathrm{pH}$ 7.2, and observed by transmission electron microscopy. In addition, we thin sectioned the bacteria to better visualize the tip organelles. In a small proportion of both P-140 and PG-18 bacteria, we observed a terminal organelle, Figures 4(A)-(D), resembling the tip organelle of $M$. pneumoniae. We did not quantify the number of bacteria producing this tip organelle but it is a fact that these organisms can produce this organelle. It is tempting to speculate that the formation of this organelle is induced by yet 
unknown environmental, bacterial and/or host signals.

Next, we performed electron microscopy on thin sections of HEp-2 cells infected with $M$. fermentans P-140 at six hours post-infection, Figures 5(A)-(D). We were notable to capture bacteria adhering through the tip organelle, as illustrated in previous figures; however the possibility that the tip organelle is involved in the interaction between the bacteria and host cells cannot be excluded because of these observations.

\section{Discussion}

Mycoplasmas are characterized by the lack of cellular wall [1] [7] and possess only acellular membrane made up of proteins and lipids. Certain mycoplasmal membrane proteins on the microorganism's surface may display

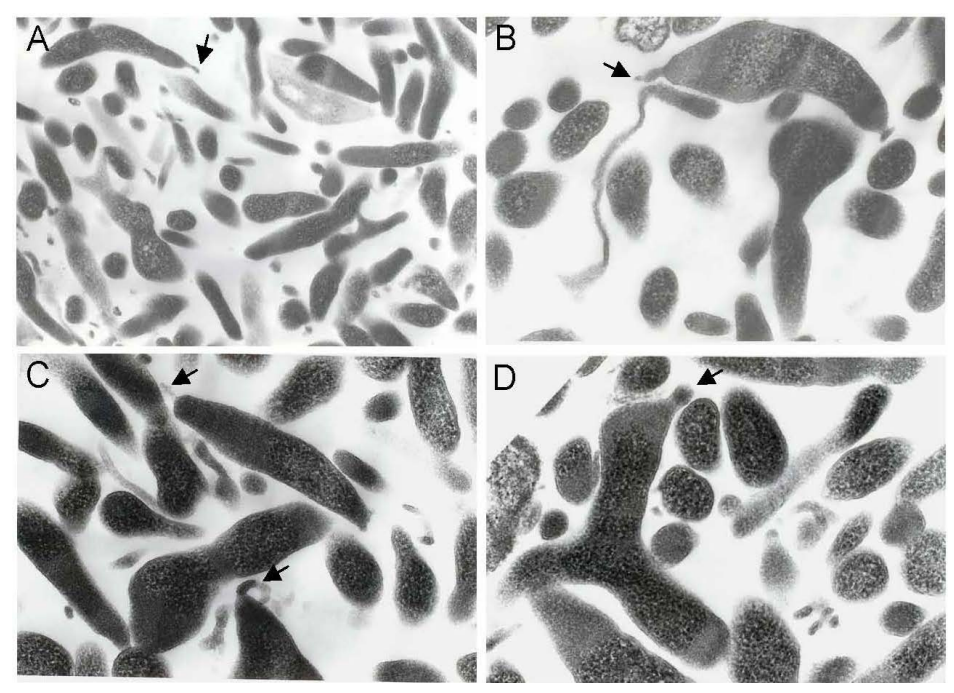

Figure 4. Ultrastructural analysis of M. fermentans cultures. The micrograph shows the characteristic shape structure of P-140 mycoplasma. The terminal organelle structure like tip organelle of $\mathrm{M}$ pneumoniae was observed in small proportions in both bacteria. It is indicated by arrows.
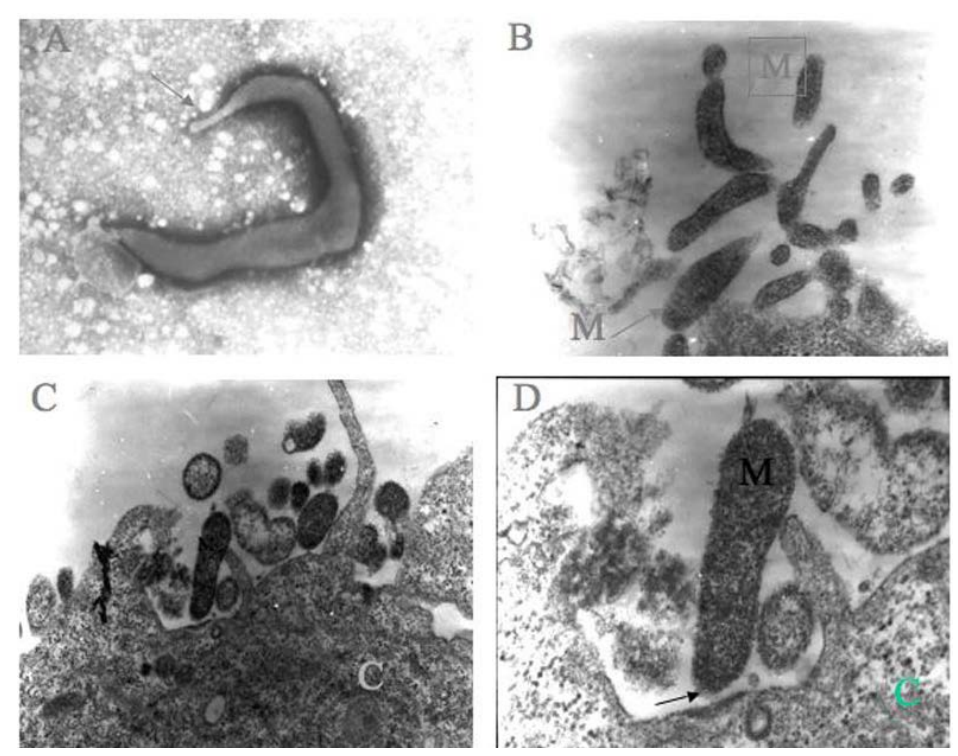

Figure 5. Electron micrograph of adherence of M. fermentans. Thin section of HEp-2 cells infected with M. fermentans P-140 to $6 \mathrm{~h}$. M (mycoplasmas); C (epithelial cells). The location of mycoplasma is indicated with arrows (A-D), as well the initial contact with cell. 
immunogenicity and may be involved in interactions with the host cell. All membrane lipoproteins are characterized by signal peptides similar to those found in other prokaryotic organisms [28]. Using the elution phases method developed by Bordier in 1981, agroup of lipids-associated membrane proteins (known as LAMPs) have been isolated from mycoplasmal membranes [29]. The proteins in this group are present in the mycoplasmal surface; constantly interact with molecules in the environment, and some proteins display a potent B-cell mitogenic activity [2]. Some M. fermentans and $M$. penetrans LAMPs [3] [30] [31] have been shown to be potent inductors of transcription factors such as Nuclear Factor Kappa B and activating protein 1, both of which play a major role in the stimulation of immune system cells [2] [4]. Several lipoproteins of $M$. fermentans have been reported to induce cytokine production when they come in contact with human monocytes, in addition to displaying modulatory activity in macrophages [2] [3] [30]-[32]. However, identification and characterization of $M$. fermentans adhesins and their role in virulence are still under study [33].

In order to identify surface protein(s) (SP) involved in adherence events of M. fermentans P-140 strain to epithelial cells HEp-2 cell's surface, protein extracts of $M$. fermentans PG-18 and M. fermentans incognitus strain, and M. pneumoniae Eaton strain were used to compare protein profiles between both mycoplasma species. Extraction of proteins is described in the experimental section. The analysis of M. fermentans P-140 surface-associated proteins was performed using SDS-PAGE, and the electrophoretic pattern obtained was in general similar between the strains compared, see Figure 6. No differences in protein profiles were seen between the bacteria grown in SP-4 and E-glucose culture media. Protein profiles varied among $M$. fermentans strains, particularly between P-140 and PG-18. M. fermentans incognitus showed a protein profile very similar to that of $M$. fermentans P-140 with slight differences in the concentration and molecular weight of some bands, Figure 6, lane 1, lane 2. A high molecular weight protein band (>100 kDa) was absent in PG-18 though present in P-140 and incognitus.

Heterogeneity in molecular weights of antigens or proteins from $M$. fermentans strains [15] has also been documented in M. pulmonis [34] and M. hyorhinis [35].

In M. fermentans P-140, six surface proteins with apparent molecular masses of 100, 78, 66, 47, 42, and 28 $\mathrm{kDa}$, Figure 6, lane 2, were the most prominent proteins visualized by Coomasie blue staining, named SP100, SP78, SP66, SP47, SP42, SP28. M. fermentans P-140 reacted with anti-M. fermentans surface proteins antibodies and anti-SP47 antibodies by immunoblotting, Figure 7, lane 2. SP47 antibodies were obtained injecting rabbits with the excised SP47 from polyacrylamide gels. We selected the SP47 because when we did a screening to prove the specificity of antisera against other proteins, they did not display inhibiting effects. SP47 was recognized by anti-SP47 antibodies and not by the pre immuneserum, Figure 7, lane 3 . To study the involvement of SP47 in adherence we performed inhibition studies by ELISA using different dilutions of these antibodies.

M. fermentans P-140 was used in the adherence inhibition assays since it showed a greater adherence to HEp-2 cells than PG-18 and also showed the highest virulence in inducing experimental arthritis [20] and experimental pneumonia [21].

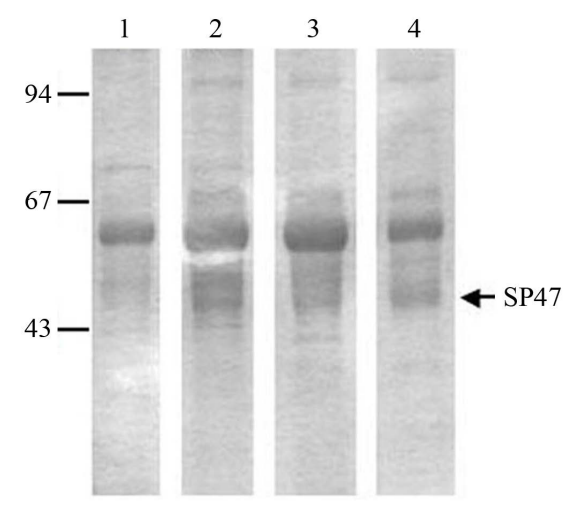

Figure 6. Profile mycoplasma proteins of $M$. fermentans. The proteins were separated by SDS-PAGE. Lane 1, Incognitus; lane 2, P-140; lane 3, PG-18; lane 4, Eaton. The Ps47 is indicated by arrow. The molecular mass standards are indicated in $\mathrm{kDa}$. 


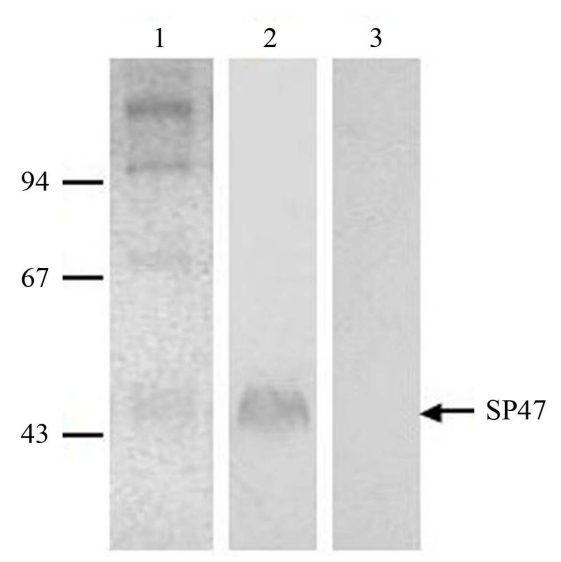

Figure 7. Immunoblotting of mycoplasma proteins. Western blot analysis of proteins extracts of $M$. fermentans P-140. Lanes: (1) The anti-mycoplasma protein antibodies recognized the protein profile; (2) The Ps47 was identified using antisera against ps47; (3) Rabbit normal sera. The molecular mass standards are indicated in $\mathrm{kDa}$.

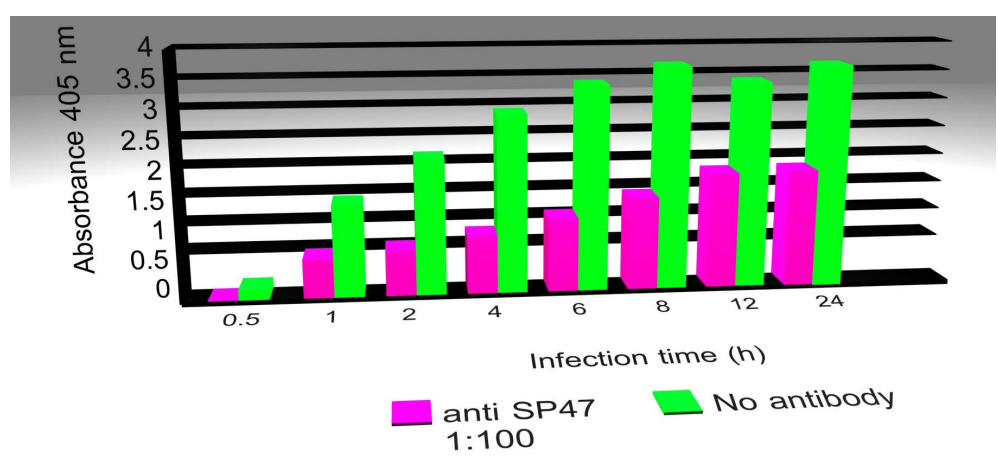

Figure 8. Adherence inhibition of $M$. fermentans p-140 to epithelial cells. The antisera against Sp47 (1:100 dilution) showed adherence inhibition to HEp-2 to the epithelial cells ( $\cdots)$. Adherence of M. fermentans P-140 to HEp2 epithelias cells $(\cdots)$. Each value represents the mean of 3 independent experiments performemed in triplicate.

Pathogenic mycoplasmas induce acute or chronic debilitating diseases and mayalter immune function. They infect mucosal surfaces, and adherence to the respiratory epithelium is an absolute requirement for successful colonization and ensuing pathogenesis. The intimate interaction between adherent mycoplasmas and hosttissue is dictated by the need to meet strict nutritional requirements [8]. M. fermentans has received attention for its potential role as a primary or contributing pathogen in human diseases; however, its pathogenic mechanisms are poorly understood. To further our knowledge on the pathogenic attributes of this pathogen, we investigated the adherence properties of two $M$. fermentans strains.

We did not see striking differences between PG-18 and P-140 in early stages of infection ( $<6$ hours) as both strains were able to adhere to cultured HEp-2 cells in a similar pattern; however, after 6 hours of infection P-140 adhered more abundantly than PG-18. This could be explained by the fact that $M$. fermentans P-140 is a more recent isolate with fewer passes in the laboratory, while the prototype strain PG-18 was isolated several decades ago from the urogenitaltract and it has been passed several times in the laboratory. Furthermore, the adherence kinetics of M. fermentans P-140 and PG-18 to HEp-2 cells was quantified by ELISA using mycoplasma-specific polyclonal antibodies.

A significant inhibition of adherence was observed when serum anti-SP47 diluted 1:100 was employed, Figure 8. Higher dilutions of the antibodies yielded less inhibition suggesting a dose-response effect. The results of these adherence assays indicate that this protein may play a role as a putative adhesin in the adherence process 
of this emergent microorganism.

\section{Conclusion}

This study showed that $M$. fermentans P-140 isolated from the human respiratory tract has the ability to adhere to human epithelial cells and to display a terminal tip-like structure observed in other mycoplasmas, including $M$. pneumoniae. The results of this study established evidence that some membrane proteins of $M$. fermentans P-140, such as SP47 may be involved in the adherence process, since serum anti-SP47 inhibited considerably the adherence of this microorganismto HEp-2 cells. Similarities in the protein profiles of $M$. fermentans incognitus strain and P-140 strains were observed. Despite our present knowledge of the various mycoplasmal virulence determinants, further evidence of the importance of interactions between eukaryotic cells and M. fermentans proteins in human infections is needed. It is also important to study adherence events in more detail asa virulence attribute that could help understand the pathogenicity mechanisms of this emergent microorganism.

\section{Acknowledgements}

Authors want to thank Elliot Heilman so much for his kind comments in reviewing this paper. We would like to thank Microscopy Centre of ENCB-IPN, UME-UCR of San José, Costa Rica for the electron photomicrographs in transmission electron microscope. ENCB-IPN supported our research. M. Rosales-Pérez was supported by a scholarship No. 91996 from Consejo Nacional de Ciencia y Tecnología (CONACYT) México.

\section{References}

[1] Rotten, S. and Yehudith, N. (1998) Subversion and Exploitation of Host Cellsby Mycoplasmas. IEEE Transactions on Instrumentation and Measurement, 6, 436-441.

[2] Kostyal, D.A., Butler G.H. and Beezhold, D.H. (1994) A 48 Kilodalton Mycoplasma fermentans Membrane Protein Induces Cytokine Secretion by Humanmonocytes. Infection and Immunity, 62, 3793-3800.

[3] Rawadi, G. and Roman-Román, S. (1996) Mycoplasma Membrane Lipoproteins Induce Proinflammatory Cytokines by a Mechanism Cytokines by a Mechanism Distinct from That of Lipopolysaccharide. Infection and Immunity, 64, 637643.

[4] Razin, S. and Jacobs, E. (1992). Mycoplasma Adhesion. Journal General Microbiology, 138, 407-422. http://dx.doi.org/10.1099/00221287-138-3-407

[5] Cassell, G.H. and Cole, B.C. (1981) Mycoplasmas as Agents of Human Disease. New England Journal of Medicine, 304, 80-89. http://dx.doi.org/10.1056/NEJM198101083040204

[6] Baseman, J.B. and Tully, J.G. (1997) Mycoplasmas: Sophisticated, Reemerging, Andburdened by Their Notoriety. Emerging Infectious Diseases, 3, 21-32. http://dx.doi.org/10.3201/eid0301.970103

[7] Ueno, P.M., Timenetsky, J., Centonze, V.E., Wewer, J.J., Cagle, M., Stein, M.A., Krishnan, M. and Baseman, J.B. (2008) Interaction of Mycoplasma genitalium with Host Cells: Evidence for Nuclear Localization. Microbiology, 154, 3033-3041. http://dx.doi.org/10.1099/mic.0.2008/020735-0

[8] Krause, D.C. (1998) Mycoplasma pneumoniae Cytadherence: Organization Andassembly of the Attachment Organelle. IEEE Transactions on Instrumentation and Measurement, 6, 15-19.

[9] Krause, D.C. and Baseman, J.B. (1982) Mycoplasma pneumoniae Proteins That Selectively Bind to Host Cells. Infection and Immunity, 37, 382-386.

[10] Zhang, Q. and Wise K. (1996) Molecular Basis of Size and Antigenic Variation of a Mycoplasma hominis Adhesin Encoded by Divergent vaa Genes. Infection and Immunity, 64, 2737-2744.

[11] Girón, J.A., Lange, M. and Baseman, J.B. (1996) Adherence, Fibronectin Binding, and Induction of Cytoskeleton Reorganization in Cultured Human Cells by Mycoplasma penetrans. Infection and Immunity, 64, 197-208.

[12] Saada, A.B., Terespolski, Y., Adoni, A. and Kahane, I. (1991) Adherence of Ureaplasma urealyticum to Human Erythrocytes. Infection and Immunity, 59, 467-469.

[13] Wise, K.S., Kim, H.F., Theiss, P.M. and Lo, S.C. (1993) A Family of Strain-Variant Surface Lipoproteins of Mycoplasma fermentans. Infection and Immunity, 61, 3327-3333.

[14] Wise, K.S., Foecking, M.F., Röske, K., Lee, Y.J., Lee, Y.M., Madan, A. and Calcutt, M.J. (2006) Distinctive Repertoire of Contingency Genes Conferring Mutation-Based Phase Variation and Combinatorial Expression of Surface Lipoproteins in Mycoplasma capricolum subsp. Capricolum of the Mycoplasma mycoides Phylogenetic Cluster. Journal of Bacteriology, 188, 4926-4941. http://dx.doi.org/10.1128/JB.00252-06 
[15] Stadtlander, C.T., Zuhua, C., Watson, H.L. and Cassell, G.H. (1991) Protein and Antigen Heterogeneity among Strains of Mycoplasma fermentans. Infection and Immunity, 59, 3319-3322.

[16] Theiss, P.M., Kim, M.F. and Wise, K.S. (1993) Differential Protein Expression and Surface Presentation Generates High-Frequency Antigenic Variation in Mycoplasma fermentans. Infection and Immunity, 61, 5123-5128.

[17] Horowitz, S., Evison, B., Borer, A. and Horowitz, J. (2000) Mycoplasma fermentans in Rheumatoid Arthritis and Other Inflammatory Arthritides. Journal of Rheumatology, 27, 2747-2753.

[18] Haier, J., Nasralla, A., Franco, R. and Nicolson, G.L. (1999) Detection of Mycoplasmal Infections in Blood of Patients with Rheumatoid Arthritis. Rheumatology, 38, 504-509. http://dx.doi.org/10.1093/rheumatology/38.6.504

[19] Johnson, S., Sidebottom, D., Bruckner, F. and Collins, D. (2000) Identification of M. fermentans in Synovial Fluid Samples from Arthritis Patients with Inflammatory Disease. Journal of Clinical Microbiology, 38, 90-93.

[20] Rivera, A., Yáñez, A., León-Tello, G., Gil, C., Giono, S., Barba, E. and Cedillo, L. (2002) Experimental Arthritis Induced by a Clinical Mycoplasma fermentans Isolate. BMC Musculoskeletal Disorders, 3, 15-21. http://dx.doi.org/10.1186/1471-2474-3-15

[21] Yáñez, A., Martínez-Ramos, A., Calixto, T., González-Matus, F.J., Rivera-Tapia, J.A., Giono, S., Gil, C. and Cedillo, L. (2013) Animal Model of Mycoplasma fermentans Respiratory Infection. BMC Research Notes, 6, 9. http://www.biomedcentral.com/1756-0500/6/9 http://dx.doi.org/10.1186/1756-0500-6-9

[22] Kannan, T.R., Provenzano, D., Wright, J.R. and Baseman, J.B. (2005) Identification and Characterization of Human Surfactant Protein A Binding Protein of Mycoplasma pneumoniae. Infection and Immunity, 73, 2828-2834. http://dx.doi.org/10.1128/IAI.73.5.2828-2834.2005

[23] Harlow, E. and Lane, D. (1988) Immunobloting and Immunoassay. In: Harlow, E. and Lane, D., Eds., Antibodies: A Laboratory Manual, Cold Spring Harbor Laboratory Press, New York, 471-553.

[24] Laemmli, U.K. (1970) Cleavage of Structural Proteins during the Assembly of the Head of Bacteriophage T4. Nature, 227, 680-685. http://dx.doi.org/10.1038/227680a0

[25] Baseman, J.B., Reddy, S.P. and Dallo, S.F. (1996) Interplay between Mycoplasma Surface Proteins, Airway Cells, and the Protean Manifestations of Mycoplasma-Mediated Human Infections. American Journal of Respiratory Critical Care Medicine, 154, S137-S144. http://dx.doi.org/10.1164/ajrccm/154.4_Pt_2.S137

[26] Layh-Schmitt, G., Podtelejnikov, A. and Mann, M. (2000) Proteins Complexed to the P1 Adhesin of Mycoplasma pneumoniae. Microbiology, 146, 741-747.

[27] Zhang, Q., Young, T.E. and Ross, R.E. (1995) Identification and Characterization of a Mycoplasma hyopneummoniae Adhesin. Infection and Immunity, 63, 1013-1019.

[28] Chambaud, I., Wróblewski, H. and Blanchard, A. (1992) Interactions between Mycoplasma Lipoproteins and the Host Immune System. IEEE Transactions on Instrumentation and Measurement, 7, 493-499.

[29] Bordier, C. (1981) Phase Separation of Integral Membrane Proteins in Triton X-114 Solution. Journal of Biological Chemistry, 256, 1604-1607.

[30] Mühlradt, P.F. and Schade, U. (1991) MDHM, a Macrophage-Stimulatory Product of Mycoplasma fermentans, Leads to in Vitro Interleukin-1 (IL-1), IL-6, Tumor Necrosis Factor, and Prostaglandin Production and Is Pyrogenic in Rabbits. Infection and Immunity, 59, 3969-3974.

[31] Quentmeier, H., Schmitt, E., Kirchhoff, H., Grote, W. and Mühlradt, P.F. (1990) Mycoplasma fermentans-Derived High Molecular-Weight Material Induces Interleukin-6 Release in Cultures of Murine Macrophages and Human Monocytes. Infection and Immunity, 58, 1273-1280.

[32] Girón, J.A., Torres, A.G., Freer, E. and Kaper, J.B. (2002) The Flagella of Enteropathogenic Escherichia coli Mediate Adherence to Epithelial Cells. Molecular Microbiology, 44, 361-379. http://dx.doi.org/10.1046/j.1365-2958.2002.02899.x

[33] Leigh, S.A. and Wise, K.S. (2002) Identification and Functional Mapping of the Mycoplasma fermentans P29 Adhesin. Infection and Immunity, 70, 4925-4935. http://dx.doi.org/10.1128/IAI.70.9.4925-4935.2002

[34] Beyers, T.M., Lai, W.C., Read, R.W. and Pakes, S.P. (1994) Mycoplasma pulmonis 46-KDa Trypsin-Resistant Protein Adheres to Rat Tracheal Epitelial Cells. Laboratory Animal Science, 44, 573-578.

[35] Citti, C., Watson-McKown, R., Droesse, M. and Wise, K.S. (2000) Gene Families Encoding Phase- and Size-Variable Surface Lipoproteins of Mycoplasma hyorhinis. Journal of Bacteriology, 182, 1356-1363.

http://dx.doi.org/10.1128/JB.182.5.1356-1363.2000 
Scientific Research Publishing (SCIRP) is one of the largest Open Access journal publishers. It is currently publishing more than 200 open access, online, peer-reviewed journals covering a wide range of academic disciplines. SCIRP serves the worldwide academic communities and contributes to the progress and application of science with its publication.

Other selected journals from SCIRP are listed as below. Submit your manuscript to us via either submit@scirp.org or Online Submission Portal.
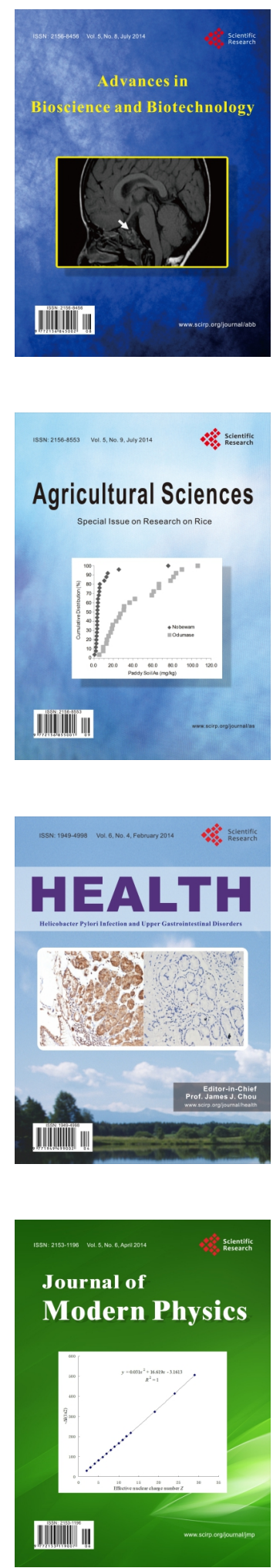
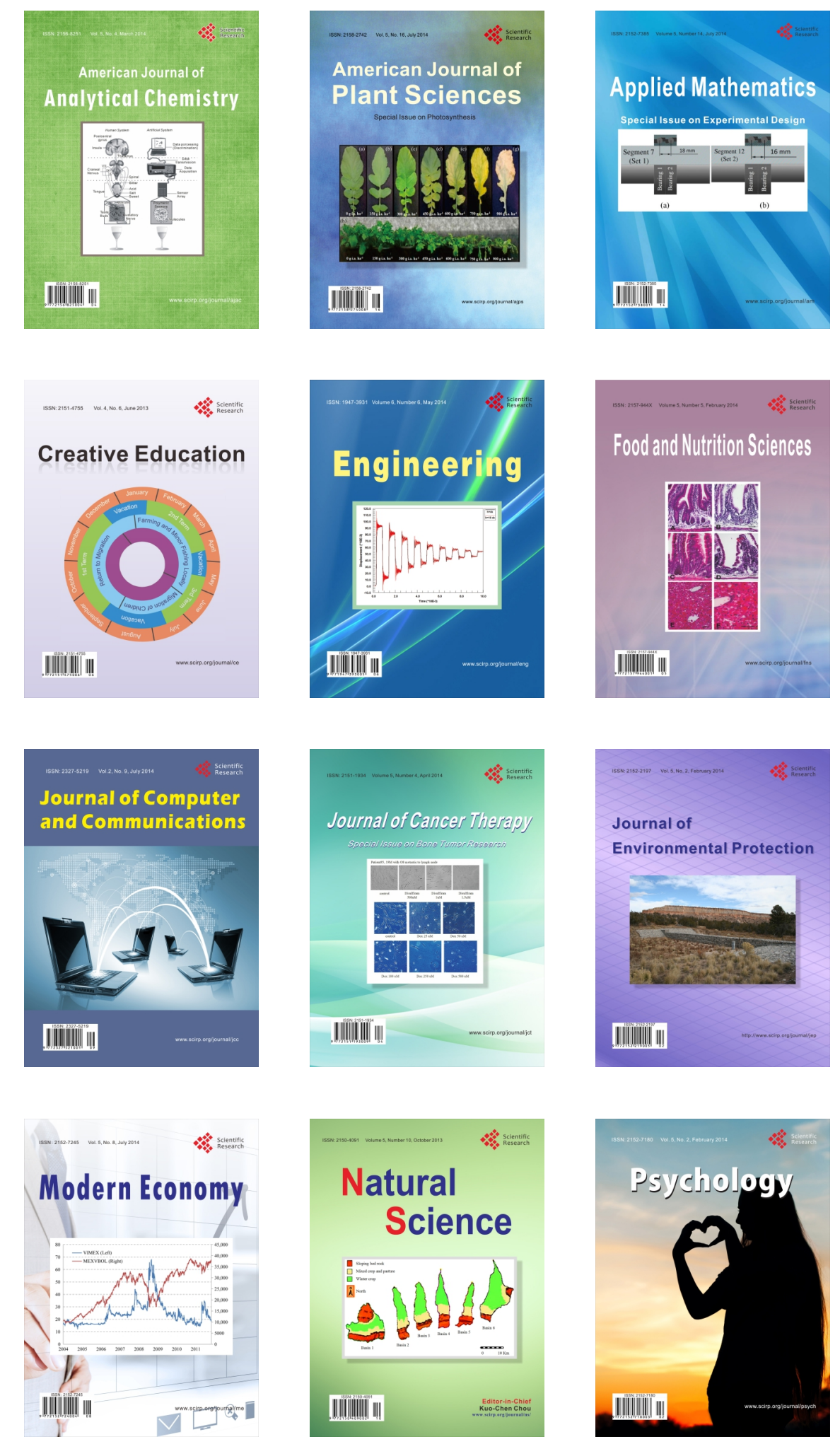